О. П. Волосовець, С. П. Кривопустов, В. Є. Хоменко, О. В. Мозирська

Національний медичний університет імені О. О. Богомольця, м. Київ

\title{
СУЧАСНІ ТЕХНОЛОГІЇ ВИКЛАДАННЯ ТЕМИ “ФУНКЦІОНАЛЬНІ ГАСТРОІНТЕСТИНАЛЬНІ РОЗЛАДИ У ДІТЕЙ (ВІДПОВІДНО ДО РИМСЬКИХ КРИТЕРІЇВ IV)” НА VI КУРСІ МЕДИЧНОГО ФАКУЛЬТЕТУ
}

\author{
O. P. Volosovets, S. P. Kryvopustov, V. Ye. Khomenko, O. V. Mozyrska \\ Bogomolets National Medical University, Kyiv \\ MODERN TECHNOLOGIES OF TEACHING TOPIC “CHILDHOOD \\ FUNCTIONAL GASTROINTESTINAL DISORDERS (ACCORDING \\ TO ROME CRITERIA IV)” FOR 6 $^{\mathrm{TH}}$ YEAR STUDENTS OF MEDICAL \\ FACULTY
}

\begin{abstract}
Мета роботи - на прикладі викладання теми “Функціональні гастроінтестинальні розлади у дітей (відповідно до Римських критеріїв IV)” розглянути можливість застосування новітніх технологій у медичній освіті для розвитку клінічного мислення та професійної компетентності майбутніх лікарів, спонукання їх до самостійної роботи, ініціативного пошуку, аналізу досліджень міжнародної групи експертів з позицій доказової медицини та самореалізації.

Основна частина. Інтеграція України в міжнародне науково-освітнє співтовариство та реформування системи охорони здоров’я в Україні потребують впровадження в освітньо-інтегративний процес міжнародних медичних та освітніх стандартів, підвищення інтелектуального, науково-освітнього, професійно-орієнтованого рівня майбутніх лікарів, забезпечення їх сучасними інноваційними та інформативними медичними технологіями. Інноваційний навчально-виховний процес повинен базуватися на засадах доказової медицини та бути орієнтованим на самостійну діяльність щодо здобуття знань, із використанням інноваційних технологій викладання, інтерактивних методик, запровадженням у навчальний процес сучасних наукових розробок.

Висновки. Реформування медичної освіти в Україні та її модернізація на засадах світових стандартів та відповідно до вимог і потреб системи охорони здоров’я країни (впровадження інноваційних технологій, проблемно-орієнтоване навчання, використання світового досвіду) формує професійну компетентність майбутнього лікаря.
\end{abstract}

Ключові слова: навчальний процес; інтерактивні методики; доказова медицина.

The aim of the study is to consider the new technologies usage in medical education to develop doctors' clinical thinking and professional competency, encourage them to work independently, carry out dynamic search and analyze the researches of international group of experts from an evidence-based medicine and self-fulfillment viewpoint as exemplified by teaching the topic "Childhood functional gastrointestinal disorders (according to Rome criteria IV)”.

The main body. The integration of Ukraine into the international academic community and health care reform in Ukraine need to be supported in the educational process of integrative international medical and educational standards, improving the intellectual, scientific, educational, profession-oriented level of future doctors, providing them with modern innovative and informative medical technologies. Innovative educational process should be based on the principles of evidence-based medicine and to be self-oriented about knowledge acquisition, using innovative teaching technologies, interactive methods, and modern scientific research implementation to educational process.

Conclusion. Reform of medical education in Ukraine and its modernization based on international standards and according to the requirements and needs of the health system of the country (innovative technologies, problem-based learning, and world experience implementation) forms professional competence of a doctor.

Key words: learning process; interactive methods; evidence-based medicine.

Вступ. Сучасні вимоги до професійної підготовки майбутніх лікарів, зумовлені інтеграцією України в міжнародне науково-освітнє співтовариство та реформуванням системи охорони здоров'я в Україні, потребують впровадження в освітньоінтегративний процес міжнародних медичних та освітніх стандартів, підвищення інтелектуально- го, науково-освітнього, професійно-орієнтованого рівня майбутніх лікарів, забезпечення їх сучасними інноваційними та інформативними медичними технологіями.

Компетентнісна, особистісно-орієнтована модель, що відображає систему професійних знань, умінь, навиків, особистісно-поведінкових якостей,

() О. П. Волосовець, С. П. Кривопустов, В. Є. Хоменко, О. В. Мозирська 
об’єднаних гуманним ставленням до пацієнта, потребує сучасних педагогічних стратегій при викладанні клінічних дисциплін.

Проблемно-орієнтоване навчання з використанням міждисциплінарного підходу та інтерактивних методів, навчання в реальних та наближених до реальних умовах медичної практики, організація творчої дослідницької діяльності студентів задля розвитку нестандартного мислення і навиків розв’язання нестереотипних професійних завдань, запровадження у навчальний процес сучасних наукових розробок та засад доказової медицини є сучасною технологією медичної освіти.

Вивчення теми на VI курсі шляхом розв’язання реальних клінічних ситуацій вимагає не тільки знань попередніх курсів педіатрії та суміжних дисциплін, але й сучасних світових підходів до діагностики та лікування [1-3].

Мета роботи - на прикладі викладання теми “Функціональні гастроінтестинальні розлади у дітей (відповідно до Римських критеріїв IV)” розглянути можливість застосування новітніх технологій у медичній освіті для розвитку клінічного мислення та професійної компетентності майбутніх лікарів, спонукання їх до самостійної роботи, ініціативного пошуку, аналізу досліджень міжнародної групи експертів з позицій доказової медицини та самореалізації.

Основна частина. Найбільшу вагу в структурі патології органів травлення у дітей мають функціональні захворювання. Використання світового досвіду та уніфікованого підходу з позицій доказової медицини (за Римськими критеріями) допомагає професійно діагностувати порушення, пов’язані 3 травним каналом, диференціювати функціональні розлади з органічною патологією, визначати об’єм лабораторно-інструментального та медикаментозного втручання, призначати адекватне лікування.

Готуючись до практичного заняття, студенти повинні знати епідеміологію, патофізіологію функціональних гастроінтестинальних розладів у дітей. Розуміючи механізм виникнення цих нозологічних форм, використовувати нове визначення цієї патології (відповідно до Римських критеріїв IV) “розлади цереброінтестинальної взаємодії”. Треба вивчити нову класифікацію, клінічні прояви, алгоритми діагностики та лікування усіх нозологічних форм [4, 5].

Інноваційний навчально-виховний процес повинен бути орієнтованим на самостійну діяльність щодо здобуття знань. У процесі самостійної ро- боти студент повинен мати доступ до інформації, передбаченої навчальною програмою: методичні рекомендації, орієнтовна карта для організації самостійної роботи студентів, рекомендована література (у тому числі базові англомовні підручники), електронні ресурси (є пріоритетним джерелом, зважаючи на актуальність інформації). Високий рівень мотивації на навчання (відчуття обов’язку та бажання особистісного успіху) й активна позиція щодо оволодіння знаннями дозволяють студентам здобувати і конструювати знання, формувати вміння та навички, виховувати самостійність як рису характеру, вчитися в подальшому вдосконалювати свій професійний рівень [1-3, 6].

Міждисциплінарна інтеграція передбачає використання знань нормальної і патологічної анатомії та фізіології, мікробіології та імунології (структурні і функціональні особливості нервової, травної та інших систем у дітей; морфологічні зміни при запальних, алергічних процесах, синдромі мальабсорбції̈; механізми порушення моторики, вісцеральної гіперчутливості та сприйняття болю центральною нервовою системою; регуляція судинного тонусу; зміни кишкової мікрофлори та інших процесів при функціональних гастроінтестинальних розладах у дітей). На розумінні симптомів цереброінтестинальних розладів як наслідків патофізіологічних процесів було наголошено в Римських критеріях.

3 курсу пропедевтичної педіатрії студенти повинні знати основні симптоми і синдроми, пов'язані з патологією травного каналу; вміти збирати анамнез, проводити клінічне обстеження дітей, вміти доглядати за дітьми, годувати та складати дієтичне меню. Вивчення педіатрії на IV-V курсах та в курсі дитячих інфекційних хвороб вимагає знань етіології, патогенезу та клініки захворювань з абдомінальним синдромом, порушенням випорожнень, нудотою, блюванням та іншими диспептичними симптомами, синдромом мальабсорбції тощо, а також вмінь призначати обстеження, діагностувати та лікувати ці захворювання.

Знання фармакології про фармакодинаміку, фармакокінетику та побічну дію препаратів дозволяють визначати показання до призначення етіотропного, патогенетичного та симптоматичного лікування. Використовуючи базові знання з психології та психотерапії, майбутні лікарі зможуть спілкуватися з батьками в напрямку немедикаментозної корекції цереброінтестинальних розладів у дитини. Внутрішньопредметна інтеграція перед- 
бачає наявність вмінь диференційної діагностики захворювань дихальної, серцево-судинної, сечової, травної та інших систем і визначення тактики при інтегрованому веденні хвороб дитячого віку.

На підготовчому етапі заняття для контролю вихідного рівня знань, навичок та вмінь проводиться тестовий контроль із можливим використанням високопрофесійних оригінальних тестових завдань міжнародного зразка; вирішення типових клінічних задач; курація хворих, які мають абдомінальний синдром, диспептичні явища, патологію травного каналу, з демонстрацією навичок фізикального обстеження, вмінь діагностувати та складати план лікування.

Використання інтерактивних методів навчання 3 організацією продуктивної взаємодії студентів між собою сприяє засвоєнню нового досвіду, отриманню нових знань і надає можливість для самореалізації особистості. В процесі теоретичного контролю можливо застосування методу діалогу, дискусії (студентів між собою та викладача зі студентом). Необхідно акцентувати увагу на нових нозологічних формах та змінах в критеріях діагностики існуючих функціональних розладів.

Цереброінтестинальні розлади пропонується класифікувати за комбінацією наступних симптомів: порушення моторики, вісцеральна гіперчутливість, зміни слизової оболонки та імунної відповіді, зміни кишкової флори. В Римських критеріях затверджена роль мікроорганізмів та деяких харчових продуктів у виникненні цереброваскулярних розладів; введені терміни: “гіперчутливий рефлекс”, “синдром хронічної нудоти”, “синдром хронічного блювання”; термін “функціональний абдомінальний біль” змінено на "порушення сприйняття гастроінтестинального болю”; обгрунтовані критерії діагностики “епігастрального больового синдрому”, “постпрандіального дистрес-синдрому” та їх поєднання; змінено критерії діагностики синдрому подразненого кишечнику та виділені підтипи цього стану; затверджений “синдром перехресту цереброінтестинальних розладів”, що супроводжується одночасним перебігом декількох функціональних станів.

Доречно наголосити, що встановлення розладів гастроінтестинальної взаємодії базується, значною мірою, на скаргах (батьків або дітей старшого віку), що передбачає необхідність взаємодії з батьками при діагностиці та реалізації терапевтичних заходів. Важливо пам'ятати про роль немедикаментозних методів лікування розладів цереброінтестинальної взаємодії, необхідності психологічної підтримки [1, 4-6].
На основному етапі заняття для формування професійних вмінь (70 \% часу) відбувається тренінг у вирішенні ситуаційних задач: реальних клінічних при курації хворих, за відеоматеріалами, за історіями хвороб, текстових нетипових ситуаційних задач (без достатньої кількості даних, з надлишковими даними, з частково неправильними даними, 3 можливими декількома варіантами вирішення, 3 атиповою клінікою чи супутніми захворюваннями, з потребою складної диференційної діагностики, невідкладної допомоги або пошуку професійних помилок тощо).

Важливим € вдосконалення вмінь диференційної діагностики з органічними патологічними станами, призначення адекватного обстеження у дітей 3 недостатнім збільшенням маси, лихоманкою, постійним плачем, рецидивуючим блюванням або порушенням випорожнень із домішками крові, слабким смоктанням, кволістю, порушенням дихання, нічними симптомами тощо для діагностики інфекційних захворювань, вад розвитку та органічних захворювань травного каналу або інших систем, синдрому мальабсорбції тощо [2, 5, 6].

3'ясувати важливі дані анамнезу, зосередитись на головних клінічних симптомах, скласти план обстеження, інтерпретувати лабораторно-інструментальні дані, провести диференційну діагностику, визначити діагноз, призначити лікування, надати невідкладну допомогу дозволяє групова робота, взаємодія студентів між собою, з викладачем, 3 навчальною інформацією.

Запровадження одночасної спільної (фронтальної) роботи всієї групи студентів, обговорення проблеми в загальному колі, круглі столи, майстер-класи, технологія “мікрофон” (надає можливість кожному сказати щось швидко, по черзі, відповідаючи на запитання або висловлюючи свою думку чи позицію), інтерактивна технологія колективного обговорення “мозковий штурм” (вироблення кількох рішень конкретної проблеми в результаті вільного висловлювання студентами своїх думок), метод ділової гри; дискусійні методи (студенти з викладачем, студенти між собою) та інші інтерактивні технології допомагають якісно формувати професійні вміння. При цьому предметом дискусії можуть бути не тільки проблеми розладів цереброінтестинальної взаємодії у дітей, але й моральні аспекти.

Майбутній лікар повинен не тільки мати знання та вміння, але й навчитись спілкуватись із хворою дитиною, формувати відношення з його батьками, виховувати в собі моральні якості (терпимість, спів- 
чуття тощо), розуміти професійну відповідальність та деонтологічні принципи. Розвитку творчої активності та мислення майбутніх лікарів допомагає не тільки вирішення задач із пошуком нових знань та способів дії, але й групова або індивідуальна науково-дослідницька робота [6].

На заключному етапі заняття (15 \% часу) відбувається аналіз та оцінка результатів клінічної роботи студентів, корекція рівня професійних вмінь та практичних навичок, аналіз рішення нетипових ситуаційних задач, оцінювання студентів, надається завдання для домашньої самостійної роботи.

\section{Список літератури}

1. Сибірцев В. Професійна компетентність учасників інноваційного навчально-виховного процесу у вищому навчальному закладі / В. Сибірцев // Теорія та методика управління освітою. - 2010. - № 3. - С. 1-10.

2. Програма розвитку вищої медичної освіти до 2015 року [Електронний ресурс]. - http://www.moz.gov.ua/ua/ portal/dn_201012227_p.html41.

3. Проблеми та перспективи вищої медичної освіти у реалізації Національної стратегії реформування системи охорони здоров'я в Україні / В. М. Мороз, Ю. Й. Гумінський, Л. В. Фоміна [та ін.] // Проблеми та перспективи вищої медичної школи у розробці та реалізації На-

\section{References}

1. Sybirtsev, V. (2010). Profesiina kompetentnist uchasnykiv innovatsiinoho navchalno-vykhovnoho protsesu u vyshchomu navchalnomu zakladi [Professional competency of innovative educational process members at higher educational institution]. Teoriia ta metodyka upravlinnia osvitoiu - Theory and methods of education management, 3, 1-10 [in Ukrainian].

2. Ministry of Healthcare of Ukraine (2010). Prohrama rozvytku vyshchoi medychnoi osvity do 2015 roku [Higher medical education development programme till 2015]. Retrieved from http://www.moz.gov.ua/ua/portal/ dn_201012227_p.html41.[in Ukrainian].

3. Moroz, V.M., Huminskyi, Yu.Y., Fomina, L.V., \& oth. (2015). Problemy ta perspektyvy vyshchoi medychnoi osvity u realizatsii Natsionalnoi stratehii reformuvannia systemy okhorony zdorovia v Ukraini [Problems and prospects for higher medical education within National reformation of healthcare system in Ukraine implementation]. Problemy ta perspektyvy vyshchoi medychnoi shkoly u rozrobtsi ta realizatsii Natsionalnoi stratehii pobudovy novoi systemy
Висновки. Шлях до отримання гарантованої якісної медичної допомоги в Україні лежить у тому числі і через реформування медичної освіти. Її модернізація на засадах світових стандартів та відповідно до вимог і потреб системи охорони здоров’я країни (впровадження інноваційних технологій, проблемно-орієнтоване навчання, використання світового досвіду) формує професійну компетентність майбутнього лікаря. Це розглянуто на прикладі практичного заняття “Функціональні гастроінтестинальні розлади у дітей” зі студентами VI курсу медичного факультету.

ціональної стратегії побудови нової системи охорони здоров’я в Україні на період 2015-2025 рр. : тези доп. наук.-метод. конф. - Вінниця, 2015. - С. 2-6.

4. Childhood functional gastrointestinal disorders: child/ adolescent / J. S. Hyams, C. Di Lorenzo, M. Saps [et al.] // Gastroenterology. - 2016. - N 150 (6). - P. 1456-1468.

5. Childhood functional gastrointestinal disorders: neonate/toddler / M. A. Benninga, S. Nurko, C. Faure [et al.] // Gastroenterology. - 2016. - N 150 (6). - P. 1443-1455.

6. Мілерян В. Є. Методичні основи підготовки та проведення навчальних занять в медичному вузі / В. Є. Мiлерян. - К., 2008.

okhorony zdorovia v Ukraini na period 2015-2025 rr.: tezy dop. nauk.-metod. konf. - Problems and prospects of higher medical school within National strategy for building of the healthcare system in Ukraine for the period 2015-2025 development and implementation: notes for the statement at scientific and methodological conference. Vinnytsia [in Ukrainian].

4. Hyams, J.S., Di Lorenzo, C., Saps, M., Shulman, R.J., Staiano, A., \& van Tilburg, M. (2016). Childhood functional gastrointestinal disorders: child/adolescent. Gastroenterology, 150 (6), 1456-1468.

5. Benninga, M.A., Nurko, S., Faure, C., Hyman, P.E., Roberts, I.S.J., \& Schechter, N.L. (2016). Childhood functional gastrointestinal disorders: neonate/ toddler. Gastroenterology, 150 (6), 1443-1455.

6. Milerian, V.Ye. (2008). Metodychni osnovy pidhotovky ta provedennia navchalnykh zaniat $v$ medychnomu VUZi [Methodical basis of training and classes at medical university]. Kyiv [in Ukrainian]. 